\title{
Zobrazování míchy
}

\author{
MUDr. Jiří Weichet, Ph.D., doc. MUDr. Hana Malíková, Ph.D. \\ Radiodiagnostická klinika FNKV a 3. LF UK, Praha
}

Přehledový článek shrnuje současné možnosti zobrazení míchy a jejího patologického postižení. Důraz je kladen především na magnetickou rezonanci (MR), jako na jedinou metodu prímo zobrazující míšní léze, jsou vysvětleny základní i pokročilé techniky MR zobrazování míchy a jejich úskalí. V závěrečné části je stručně probrána diferenciální diagnostika nejčastějších míšních lézí v MR obraze.

Klíčová slova: mícha, magnetická rezonance, diagnostické zobrazování.

\section{Spinal imaging}

Review article sumarises recent imaging possibilities of spinal cord and its diseases. The stress is put on the magnetic resonance imaging (MRI) as the only method for spinal cord leasion visualisation. Both basic and advanced MRI techniques and sequencies are explained, possible drawbacks included. The short differential of common spinal cord leasions in MRI is discussed at the end.

Key words: spinal cord, diagnostic imaging, magnetic resonance imaging.

\section{Úvod}

Mícha je svým uložením v kostěném páteřním kanálu obtí̌něji dostupná pro některé neinvazivní zobrazovací techniky, další významnou překážkou při jejím detailnějším zobrazování je její relativně malý rozměr, z čehož plyne nutnost dostatečně vysokého prostorového rozlišení.

Klasické rentgenové metody nejsou pro zobrazení míchy vhodné. V době preded zavedením tomografických metod bylo možné míchu zobrazit pouze neprímo při naplnění durálního vaku kontrastní látkou, tedy tzv. perimyelografií. Tato invazivní metoda vyžaduje instilaci jodové kontrastní látky intratékálně, nejčastěji lumbální, výjimečně subokcipitální punkcí. Při perimyelografii jsme schopni posoudit pouze konturu a velikost míchy, která je obklopena kontrastní látkou, metoda se osvědčila při hodnocení kompresí míchy okolními strukturami a také při diagnostice míšních tumorů, kdy byla schopna zobrazit rozšíření míchy v místě nádoru.

Velkým pokrokem pro zobrazování všech částí těla, v neposlední řadě páteře s míchou, bylo zavedení výpočetní tomografie (CT) do medicínské praxe $\vee 70$. a 80 . letech minulého století. CT zobrazující orgány těla ve vrstvách umožnilo získávat transverzální řezy páteří, nicméně pro dobré odlišení míchy od okolního mozkomíšního moku, natož pro odlišení patologických lézí v míšní tkáni nemá CT dostatečný kontrast a prímé zobrazení míchy ani na $\mathrm{CT}$ tedy není možné. Toto platí i prýi výrazném pokroku $\checkmark$ konstrukci a technologii CT prístrojů, kdy se u nynějších moderních multidetektorových CT mnohonásobně zvýšila rychlost vyšetření, řádově se zlepšilo i prostorové rozlišení (standardem je nyní izotopické rozlišení 0,5 mm ve všech směrech i méně), ale kontrast CT obrázků, daný principem metody měření zeslabení rtg záření, zůstává stejný. CT je ale stále využíváno v kombinaci s perimyelografií (CT perimyelografie či CT myelografie) $k$ detailnějšímu posouzení tvaru a velikosti míchy a jejího útlaku jinými strukturami, dále je touto metodou možno dobře zobrazit míšní kořeny (obrázek 1). CT perimyelografie je metodou volby pro morfologické posouze- ní míchy, míšních kořenů a patologických lézí v durálním vaku i extradurálně v prípadě, kdy je kontraindikováno zobrazení magnetickou rezonancí, nebo je toto vyšetření nehodnotitelné při implantovaných metalických materiálech v zobrazované oblasti páteře.

\section{Standardní zobrazování míchy magnetickou rezonancí}

Přelomem pro zobrazení míchy bylo zavedení magnetické rezonance (MR) do klinické praxe v 80. a 90. letech minulého století. MR má mezi diagnostickými zobrazovacími metodami nejlepší tkáňový kontrast a jako jediná morfologická zobrazovací metoda je schopna prímo vizualizovat míchu, diferencovat mezi šedou a bílou hmotou míšní a odlišit i různé patologické léze v míše. Na MR Ize dosáhnout i velmi dobré submilimetrové prostorové rozlišení blížící se rozlišení na CT. Běžně ale užíváme větší voxel z důvodu lepšího poměru signálu a šumu, širri vrstvy při běžném vyšetření míchy volíme $3 \mathrm{~mm}$. Pro kvalitní zobrazení je při MR nutné udržet vysokou homogenitu mag- 
Obr. 1. CT perimyelografie u pacienta s avulzí kořenů C7 a C8vpravo, transverzální a koronární rekonstrukce

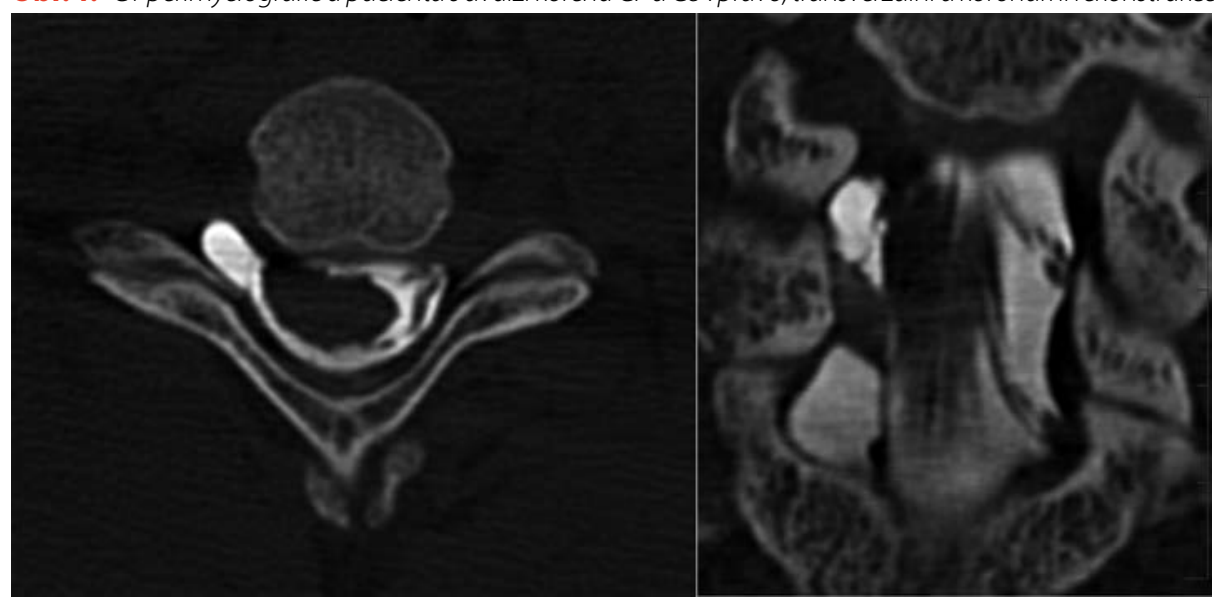

Obr. 2. Kompresivnímyelopatie u degenerativni sekundárnístenózy páteřního kanálu v úrovni Th10/11. MR zobrazenís T2 váženou sekvencí v sagitální a transverzální rovině

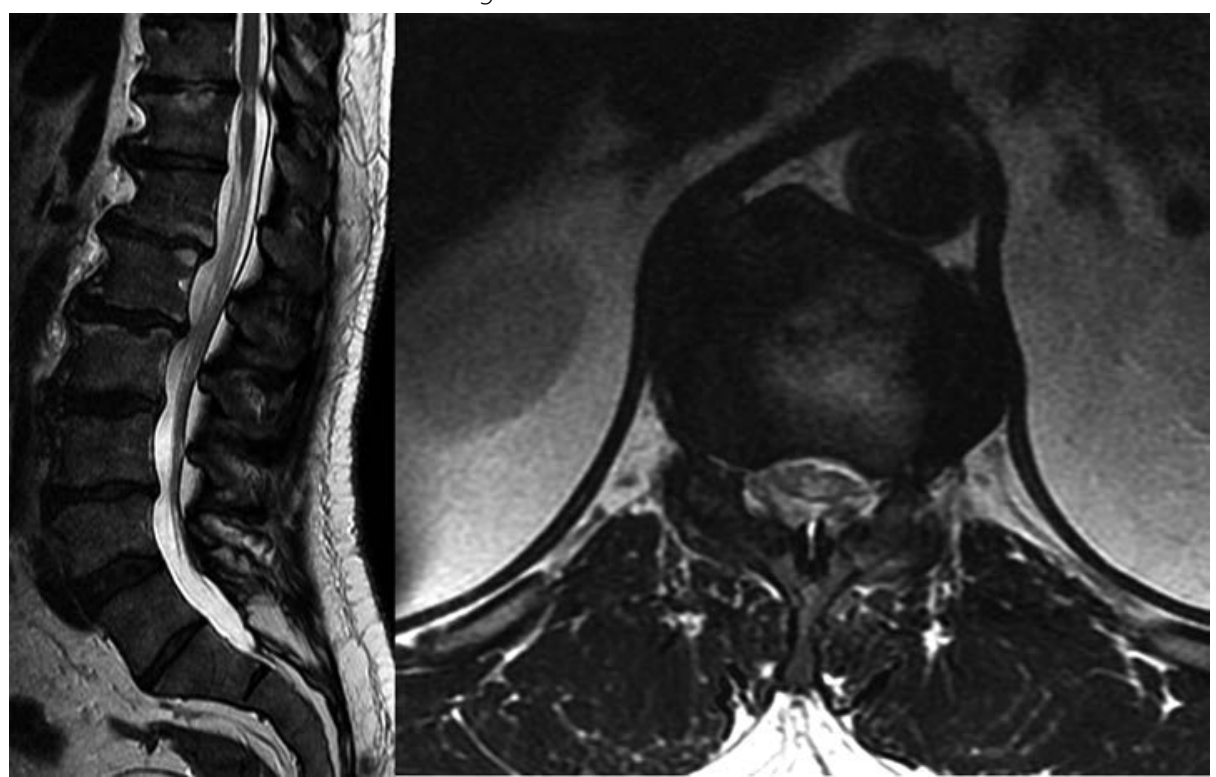

netického pole, nehomogenity pole působí na MR obrázcích různé artefakty a znehodnocují vyšetření. Struktury páteře s kombinací skeletu a měkkých tkání homogenitu magnetického pole porušují, zvláště to platí pro oblast krku a přechodu krční a hrudní páteře, kde je největší rozdíl v objemech tkání a dále jsou z tohoto hlediska problematické implantáty a cizí předměty z kovových materiálů např. v oblasti chrupu. V takových případech je někdy kvalitní MR zobrazení obtížnější (Tien, 1992). V hrudním úseku pak často působí problémy pohybové artefakty přenášené ze srdce a velkých cév. Vzhledem k pohybu míchy v závislosti na dýchání a srdeční akci i pro eliminaci artefaktů s tím spojených se uvádí, že je s výhodou využití EKG a dechové synchronizace při vyšetření, což ale standardně neprovádíme (Winklhofer et al., 2014). Zavedení MR prístrojů o síle pole 3 Tesla (T) přineslo zvýšení poměru signál/šum, což umožňuje dále zlepšit prostorové rozlišení nebo kontrast obrázků, praktický posun v zobrazení je výraznější u T2 vážených sekvencí než u T1 vážených sekvencí a dále pak samožrejmě u pokročilých MR technik (viz niže). Nicméně 3T prístroj s sebou nese i větší problémy s artefakty, které hrají prìi zobrazení míchy a páteře nezanedbatelnou roli. Navíc je důležité i další vybavení MR přístroje, nejen síla stacionárního pole, ale např̀ i síla gradientního systému a kvalita prijímacích cívek. Myslíme si tedy, že pro běžné zobrazení míchy je dostačující dobře vybavený 1,5T MR přístroj vyšší trídy s kvalitními cívkami. Síla pole nižší než 1,5T se pro zobrazení míchy nedoporučuje (Stankeiwicz et al., 2009). Pro pokročilé techniky a experimentální aplikace je 3T prístroj jistě preferován.

Při MR vyšetření páteře a míchy provádíme vždy základní sekvence v T1 a T2 vážení v sagitální rovině, standardem je i sagitální T2 vážená sekvence s potlačením signálu tuku (technikou chemické saturace nebo saturace inverzním pulzem - tzv. STIR nebo SPAIR sekvence). STIR nebo SPAIR sekvenci Ize využít ve všech oblastech, s výhodou je užívaná především v krční oblasti pro její odolnost vưči nehomogenitám magnetického pole. Druhou rovinou zobrazení u míchy je v naprosté většině volena rovina transverzální, kde standardně provádíme T2 nebo T2* vážené sekvence. Gradientní T2* vážené sekvence nejsou pro své krátké časové parametry náchylné k pulzačním a průtokovým artefaktům likvoru, a používáme je proto preferenčně v krční a hrudní oblasti. Gradientní T2* sekvence dobre diferencuje šedou a bílou hmotu, ale hưre zobrazuje skelet, tedy v prípadě, kdy je důležité i posouzení kostěných struktur páteře, není př́liš vhodná. Pokud jsou přitomny kovové implantáty, jsou T2* sekvence nevhodné, nebot trpí velkými artefakty a v tomto prípadě volíme i na krční a hrudní páteři sekvenci rychlého spinového echa (fast spin echo - FSE) v T2 vážení. Pro konfirmaci ložiskového postižení míchy lze doplnit i další sekvence - T2 se saturací tuku v transverzální rovině, protondenzitní vážení (PDW) Či fázově senzitivní inversion recovery sekvence (PSIR). Zobrazení v koronární rovině je prováděno pouze volitelně, většinou sekvencí FSE v T2 vážení. Lze jej s výhodou doplnit u nejasných nálezů na sagitální i transverzální sekvenci, také u skoliotického zakřivení páteře je někdy koronární rovina přehlednější než sagitální. U modernějších MR přístrojů jsou dostupné i T2 vážené 3D sekvence s izotopickým rozlišením, které využíváme např. pro detailnější zobrazení míšních kořenů, ve srovnání se standardními 2D sekvencemi mají ale prí dlouhých echočasech horší tkáňový kontrast a pro odlišení diskrétních intramedulárních lézí proto nejsou vhodné. Při podezření na cévní malformace míchy a intradurální cévní léze je vhodné doplnit při MR vyšetření 3D balancované gradientní sekvence (steady state free precesion - SSFP) v sagitální rovině s možnou rekonstrukcí do transverzální i koronární roviny (Krings et al., 2007). Kontrastní MR angiografii (CE-MRA) využíváme s výhodou jako neinvazivní zobrazení u cévních malformací, nebot usnadní provedení následné digitální subtrakční angiografie (DSA), která je nicméně zlatým standardem v diagnostice spinálních cévních anomálií (Saindane et al., 2015).

\section{Pokročilé MR metody}

Na rozdíl od zobrazování mozku, kde je difuzně vážená sekvence - DWI (diffusion weigh- 


\section{VLAVNÍ TÉMA}

ZOBRAZOVÁNÍIMÍCHY

Obr. 3. Komprese hrudní míchy metastázou prorůstajíci do páternního kanálu z obratlového těla Th8. MR zobrazení se sagitální T2 váženou sekvencí a STIR sekvencís potlačením signálu tuku. V dolní radě transverzální T2 vážená sekvence a stejný řez v T1 váženíse saturaci tuku po i.v. aplikaci kontrastní látky

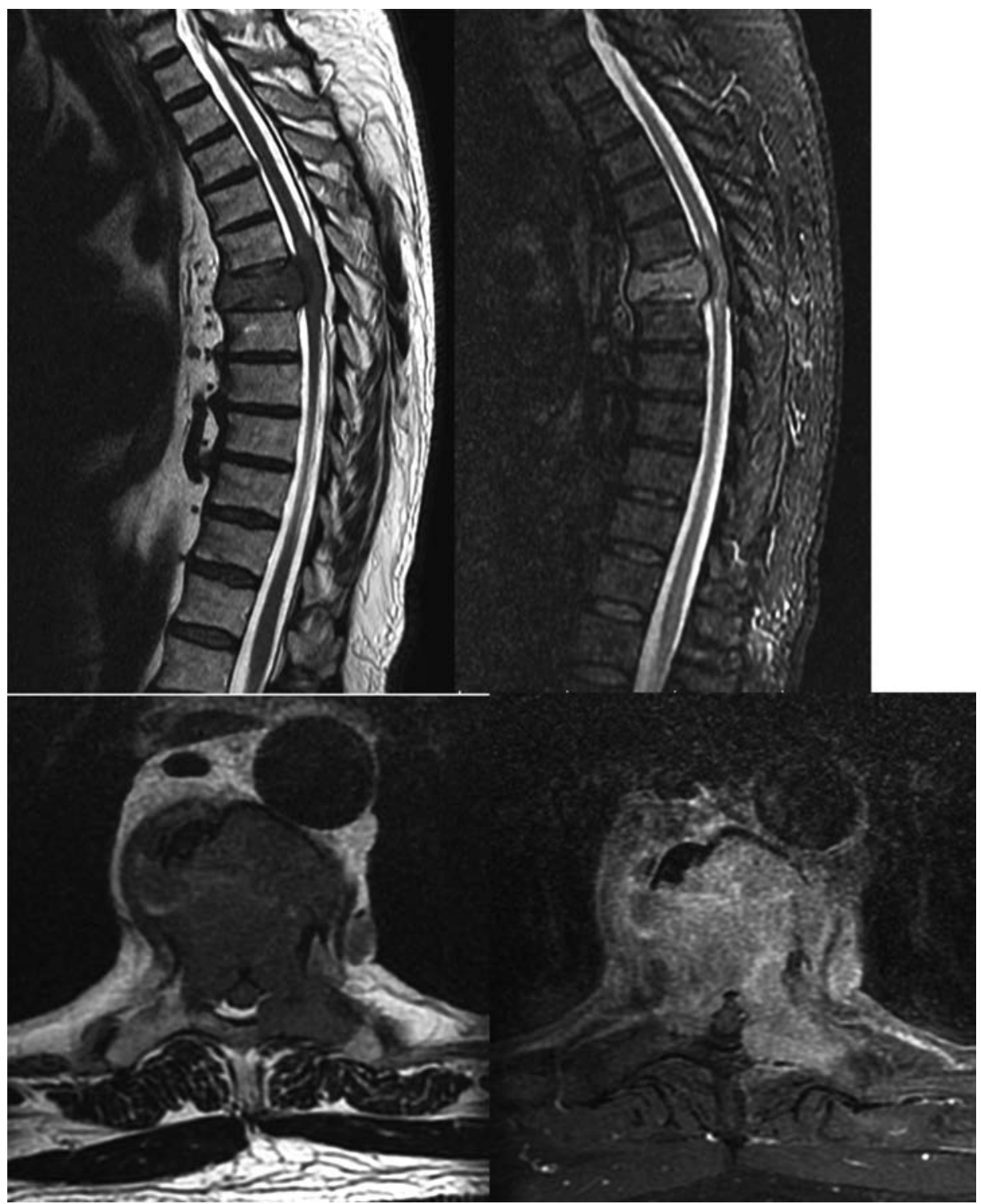

Obr. 4. RSM s plakou v dorsální a centrální části míchy v úrovni C3, MR s použitím sagitální STIR sekvence a transversální T2* sekvence

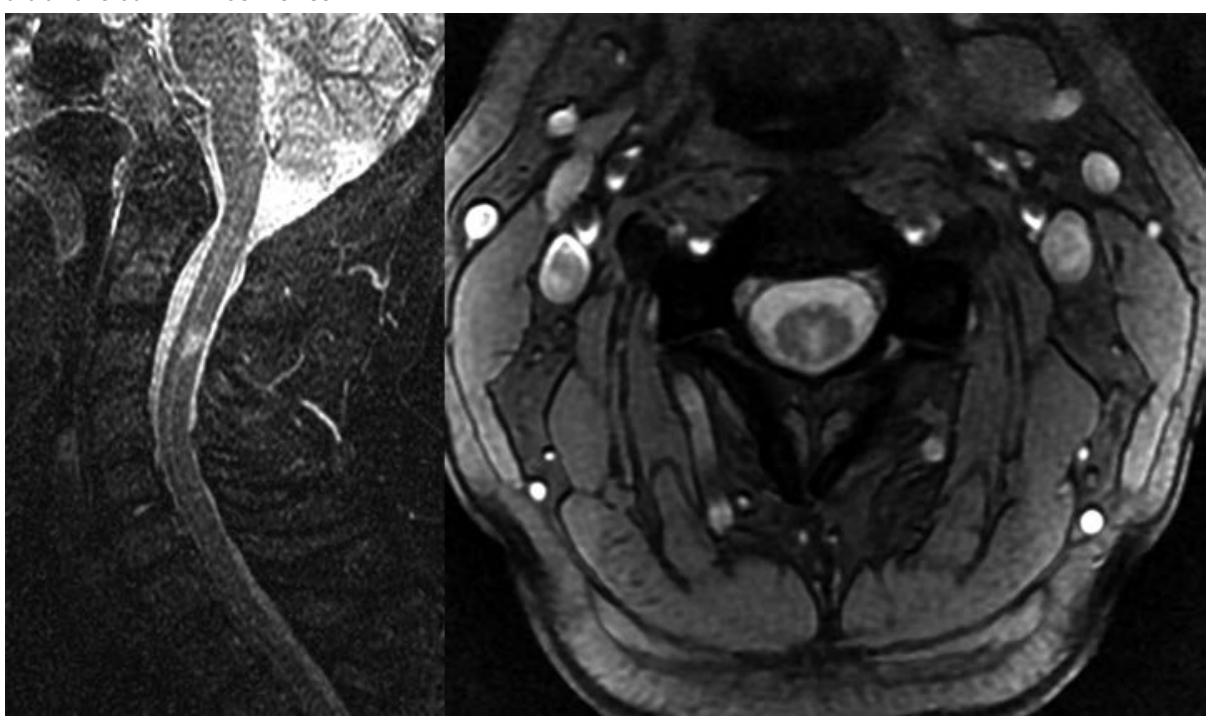

ted images), nyní již standardní součásti vyšetrovacího protokolu, u míchy je DWI používaná zatím jen málo. Vzhledem k malým rozměrưm míchy a výrazným susceptibilním artefaktům by- lo použití DWI v páteřním kanálu ještě nedávno velmi limitováno. Přesto se standardní DWI sekvence použivá při akutním míšním syndromu, nebot’ je stejně jako v mozku velmi citlivá pro detekci čerstvé ischemie míchy. Při akutní ischemii míňní, kdy ještě není patrna změna signálu na T2 vážené sekvenci, prokazujeme výrazně vysoký signál na DWI odpovídající restrikci difuze, což je typickým nálezem u akutní ischemie míchy, prostorové rozlišení zde nehraje roli. Kalkulace map aparentního difuzního parametru (ADC) je součástí vyšetřovacího protokolu, snižení signálu v této mapě potvrdí restrikci difuze a vyloučí tzv. efekt T2 prozařování (T2 shine trough), kvalita ADC mapy v oblasti páteře je ale někdy velmi nízká a její hodnocení limitováno. Obecně stále platí, že často je zobrazení difuze zcela degradováno artefakty a restrikci difuze Ize jen těžko posoudit. Restrikce difuze navíc není prítomna jen u akutní ischemie, ale též u jiných patologických stavů, např. u akutních demyelinizačních lézí (Thurnher et Bammer, 2006; Zecca et al., 2012).

Další rozvoj MR technologie a akceleračních náběrových technik umožnil v posledních letech na nejmodernějších prístrojích provádět i v oblasti míchy zobrazování směrové difuze sekvencemi DTI (diffusion tensor imaging), což bylo doposud v rozumné kvalitě a scanovacím času možné jen u MR mozku, velký význam pro umožnění těchto technik má i zavedení MR príistrojů se sílou pole 3T. Tyto metody jsou zatím využívané převážně experimentálně, stejně jako technika používající magnetizační transfer (MT). Během posledních deseti let se objevují vícečetné vědecké publikace užívající tyto metody u různých diagnóz, např. u roztroušené sklerózy mozkomíšní (RSM), traumatického postižení míchy aj. Výhodou těchto pokročilých metod je možnost kvantifikace různých parametrů v patologických lézích i v normální tkáni míchy (Wheeler-Kingshott et al., 2014). Při použití techniky MT je to např. MTR (magnetization transfer ratio), u DTI sekvencí lze kvantifikovat radiální či axiální difuzivitu nebo frakční anizotropii. Kvantifikace těchto parametrů a jejich srovnání u různých patologických stavůje dobře použitelnév experimentálních pracích, do běžné klinické praxe se zatím ale tyto metody u MR vyšetření míchy výrazněji neprosadily (Martin et al., 2015). Jako slibná se jeví i vlastní traktografie, tedy na základě směrové difuze vypočítané pravděpodobnostní průběhy jednotlivých traktů a jejich vizualizace v 2D i 3D modelu, která se zatím převážně využívá v experimentu, napřr. 
Obr. 5. RSM s vícečetnými drobnějšími plakami v krční miše, T2* transverzální sekvence. Ve vyšší etáži postižení bilé hmoty laterálních provazců oboustranně, v nižši etáži další plaka v pravém laterálním provazci

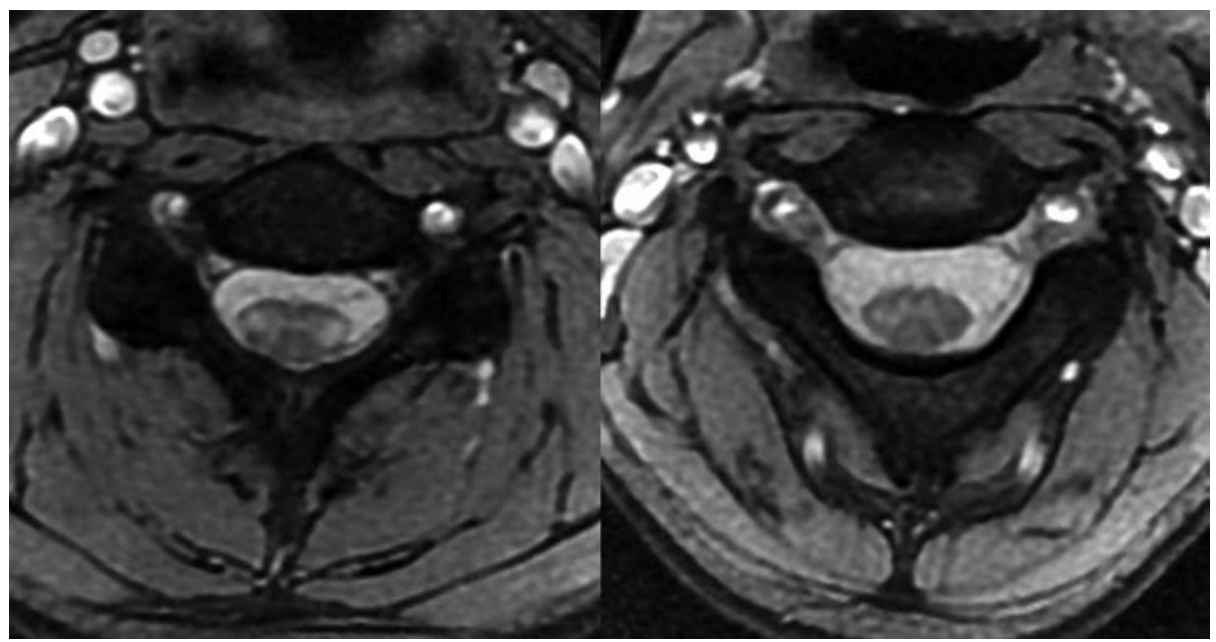

Obr. 6. Astrocytom hrudnímíchy (histologicky ověren - WHO grade II) v MR obraze - T2 vážená sekvence a T1 vážená sekvence se saturací tuku po i. v. aplikaci kontrastnílátky. Infiltrativně rostoucí rozsáhlý tumor s méně výraznou neostrou sytící se složkou

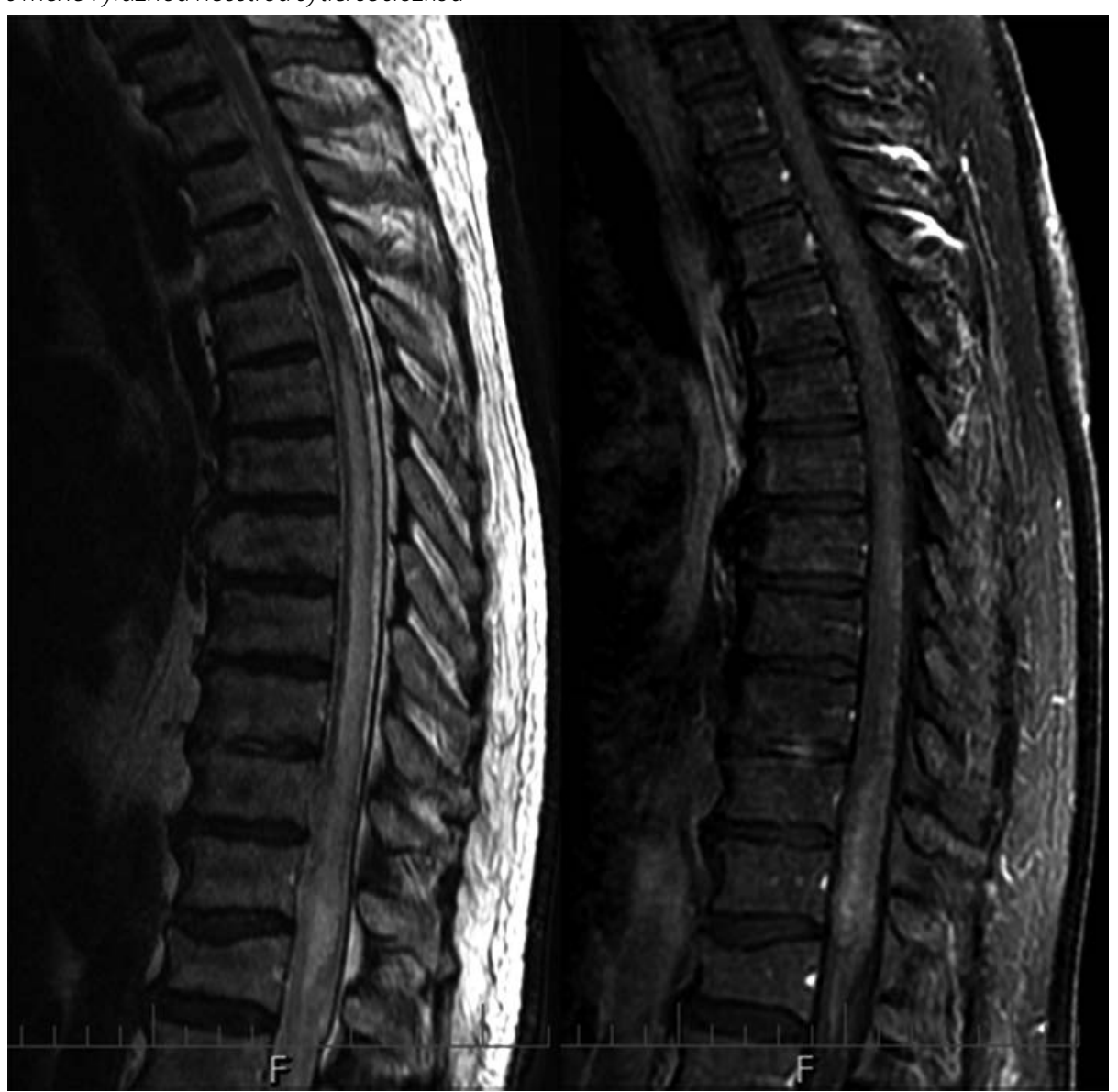

u miśních tumorů, před operací by ale mohla najít i praktické využití podobně jako traktografie v oblasti mozku a snad i pomoci v dif. dg. astrocytomu a ependymomu míchy (Ducreux et al., 2007; Landi, Palmrini et D’Elia, 2016).

\section{Diferenciální diagnostika míšních lézí v MR obraze}

Naprostá většina fokálních míšních postižení se v MR obraze projeví jako T2 hypersignální léze,
- RSM, akutní diseminovaná encefalomyelitida neuromyelitis optica (NMO), dále pak myelitida z různé etiologie (systémový lupus erythematodes, Sjögrenův syndrom, Behcetova choroba, antifosfolipidový syndrom, sarkoidóza a další), tumor míchy, postradiační myelopatie a vaskulární léze, především akutní míšní ischemie nebo cévní malformace. Jiná onemocnění vedoucí k fokálnímu míšnímu postižení jsou extrémně vzácná.

Bližší určení etiologie onemocnění lze odhadnout z rozsahu postižení míchy jak v sagitální, tak transverzální rovině. U RSM jsou demyelinizační plaky typicky menšího rozsahu, v sagitální rovině nepresahují více než dva míšni segmenty a v transverzální rovině jsou většinou omezené jen na část bílé hmoty míchy (nejčastěji laterální či zadní provazce - obrázky 4, 5), téměř nikdy není postižení míchy v rozsahu celého prưřezu na transverzální rovině (Jacob et Weinshenker, 2008). Je třeba zdůraznit, že pro diagnostiku RSM jsou rozhodující Mc Donaldova kritéria, jejichž součástí jsou i míšní ložiska (Filippi et al., 2016). Typická je pak lokalizace postižení pouze do zadních provazců míšních u deficitu vitaminu $B_{12}$. Naopak u NMO a u myelitidy je pravidlem postižení obou polovin míchy a v sagitální rovině je léze rozsáhlejší, typicky přesahuje přes dva míšní segmenty. Zduření/edém míchy je nejvýraznější u myelitidy a u tumorů míšních, u RSM a NMO nebývá zduření míchy tak výrazné. I preses tyto znaky nejsme často při prvním vyšetření schopni etiologii onemocnění na základě MR zobrazení spolehlivě určit, vždy je nutná korelace s klinickým obrazem a vyšetřením mozkomíšního moku. Výrazně pomáhá též doplnění MR vyšetření mozku, které v prípadě RSM často zobrazí další demyelinizační plaky, $\checkmark$ prípadě NMO pak můžeme odhalit postiženi optického nervu.

U ischemie míšní bývá postižení predilekčně v předních provazcích a v šedé hmotě míšní. Typické pro akutní ischemické postižení je pak výrazná restrikce difuze, kterou prokážeme na difuzně vážené sekvenci (DWI). Je-li při zobrazení zachycena i aorta, pak prítomnost její výduti a/nebo disekce pravděpodobnost míšní ischemie výrazně zvyšuje, na ischemii míšní myslíme také po chirurgických či endovaskulárních výkonech na hrudní aortě (Jacobs et al., 2016). Sycení kontrastní látkou v T1 vážení je u míšních ložisek nespecifickým znakem a je více či méně pozorovatelné 
Obr. 7. Hemangioblastom krční míchy, MR zobrazenív sagitální rovině, T2 vážená sekvence a T1 vážená sekvence nativně a po i.v. aplikaci kontrastnílátky. Tumor má cystickou a solidní, postkontrastně se sytíci složku

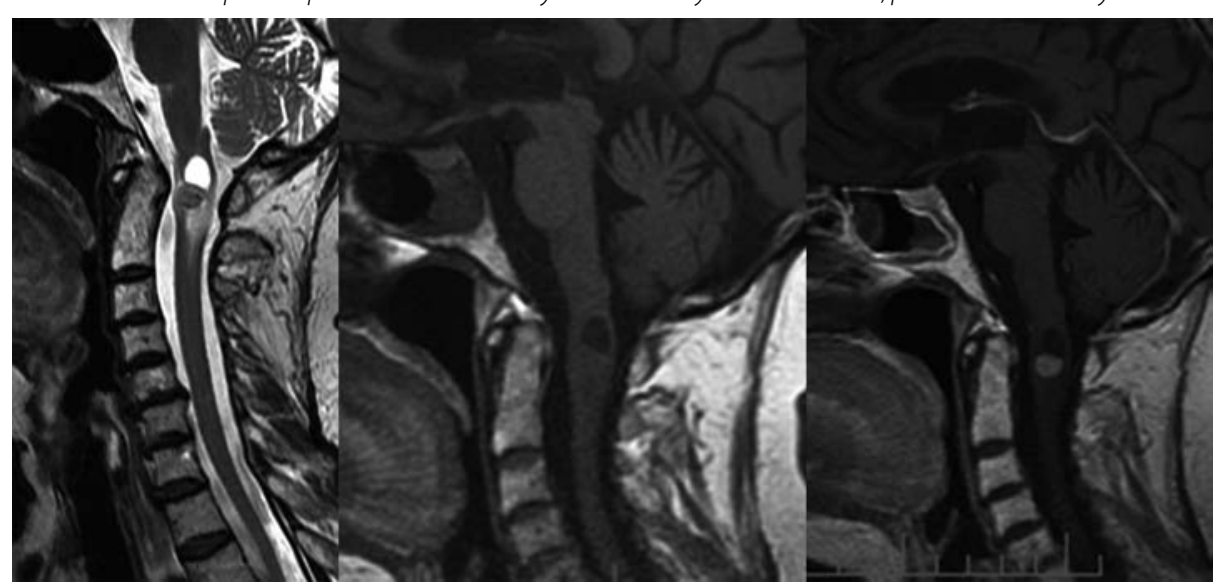

u většiny akutních a subakutních lézí zánětlivé i cévní etiologie, včetně subakutní míšní ischemie (Weidauer et al., 2015). V prípadě intradurálních arteriovenózních malformací (AVM) a píštělí zachytíme velmi často patologické, rozšířené cévy v durálním vaku v okolí míchy, k čemuž s výhodou využíváme 3D sekvence typu SSFP netrpící artefakty z pohybu likvoru. Někdy zobrazíme typický nidus AVM jako smotek drobných cév s artefakty z průtoku. Pokud je prítomno ložisko s prokrvácením různého stáří (T1 hypersignální léze obsahující extracelulární methemoglobin

\section{LITERATURA}

1. Ducreux D, Fillard P, Facon D, Ozanne A, Lepeintre JF, Renoux J, Tadié M, Lasjaunias P. Diffusion tensor magnetic resonance imaging and fiber tracking in spinal cord lesions: current and future indications. Neuroimaging Clin N Am 2007; 17(1): 137-147.

2. Filippi M, Rocca MA, Ciccarelli O, De Stefano N, Evangelou N, Kappos L, Rovira A, Sastre-Garriga J, Tintore M, Frederiksen JL, Gasperini C, Palace J, Reich DS, Banwell B, Montalban $X$, Barkhof F; MAGNIMS Study group. MRI criteria for the diagnosis of multiple sclerosis: MAGNIMS consensus guidelines. Lancet Neurol 2016; 15: 292-303.

3. Jacobs MJ, Schurink GW, Mees BM. Spinal cord ischaemia after complex aortic procedures. Eur J Vasc Endovasc Surg. 2016; 52(3): 279-280.

4. Jacob A, Weinshenker BG. An approach to the diagnosis of acute transverse myelitis. Semin Neurol. 2008; 28(1): 105-120. 5. Krings T, Lasjaunias PL, Hans FJ, Mull M, Nijenhuis RJ, Alvarez $\mathrm{H}$, Backes WH, Reinges MH, Rodesch G, Gilsbach JM, Thron AK. Imaging in spinal vascular disease. Neuroimaging Clin N Am 2007; 17: 57-72.

6. Landi A, Palmarini V, D'Elia A. Magnetic resonance diffusion tensor paging and fiber- tracking diffusion tensor tractography in the management of spinal astrocytomas. World J Clin Cases. Jan 16, 2016; 4(1): 1-4. i výpadky signálu při př́tomnosti hemosiderinu), pak pomýšlíme na kavernózní angiom.

Nejčastějšími tumory míchy jsou astrocytom, ependymom a hemangioblastom, dále přicházejí do úvahy metastázy do míchy. Astrocytomy jsou častěji lokalizovány v krční míše, mohou mít vedle solidní i cystické porce a mohou mít expanzivní ale i infiltrativní růst (Samartzis et al., 2015) (obrázek 6). Pro ependymom pak svědčí centrální lokalizace tumoru v souvislosti s centrálním kanálkem míšním, někdy bývá i prokrvácený. Ependymomy se vyskytují v krční a dále

7. Martin AR, Aleksanderek I, Cohen-Adad J, Tarmohamed Z, Tetreault L, Smith N, Cadotte DW, Crawley A, Ginsberg H, Mikulis DJ, Fehlings MG. Translating state-of-the-art spinal cord MRI techniques to clinical use: A systematic review of clinical studies utilizing DTI, MT, MWF, MRS, and fMR. Neuroimage Clin. 2015; 10: 192-238.

8. Rege SV, Narayan S, Patil H, Songara AJ. Spinal myxopapillary ependymoma with interval drop metastasis presenting as cauda equina syndrome: case report and review of literature. Spine Surg. 2016; 2(3): 216-221.

9. Ross JS, Moore KR. Diagnostic imaging - spine, Philadelphia. Elsevier 2015: 1163.

10. Saindane AM, Boddu SR, Tong F, Dehkharghani S, Dion JE. Contrast-enhanced time-resolved MRA for pre-angiographic evaluation of suspected spinal dural arterial velus fistulas. J Neurointerv Surg. 2015; 7(2): 135-140.

11. Samartzis D, Gilli CS, Shih P, O'Toole JE, Fessler RG. Intramedullary spinal cord tumors: part I - epidemiology, pathophysiology, and diagnosis. Global Spine J 2015; 05(05): 425-435.

12. Stankiewicz JM, Neema M, Alsop DC, Healy BC, Arora A, Buckla GJ, Chitnis T, Guttmannn CR, Hackney B, Bakshi R. Spinal cord lesions and clinical status in multiple sclerosis: a $1.5 \mathrm{~T}$ and 3 T MRI study. J Neurol Sci 2009; 279: 99-10. pak i v kaudální části míchy a filum terminale. Ependymom a hemangioblastom mají expanzivní charakter růstu (obrázek 7). U ependymomu je třeba zmínit, že vzhledem k možnosti jeho metastazování likvorovými cestami, je zde vhodné doplnit MR zobrazení celé kraniospinální osy (Rege et al., 2016). Hemangioblastom bývá uložen dorzálně, je dobře ohraničen a typicky obsahuje cystickou složku se solidním, sytícím se uzlem. Nicméně všechny míšní tumory se ve velké většině sytí po podání kontrastní látky a jejich odlišení je i přes výše uvedené rozdíly často obtížné (Ross et Moore, 2015). V okolí míšních tumorů bývá někdy př́tomna i rozsáhlejší syringomyelická dutina. Najdeme-li tedy syringomyelii, měli bychom vyšetřit celou míchu k vyloučení možného míšního tumoru.

\section{Závěr}

MR je jednoznačnou metodou volby pro zobrazení míchy, jako jediná grafická metoda prímo vizualizuje míchu a je schopna diferencovat její různé patologické stavy. Ačkoliv má MR vysokou senzitivitu, stále i přes pokročilá technická vybavení MR př́istrojů obecně platí, že specificita MR je v diagnostice míšních lézí nižší.

13. Thurnher MM, Bammer R. Diffusion weighted MR imaging (DWI) in spinal cord ischemia. Neuroradiology 2006; 48(11): 795-801.

14. Tien RD. Fat-suppression MR imaging in neuroradiology: techniques and clinical application. American Journal of Roentgenology 1992; 158: 369-379.

15. Weidauer S, Nichtweiss M, Hattingen E, Berkefeld J. Spinal cord ischemia: aetiology, clinical syndromes and imaging features. Neuroradiology 2015; 57(3): 241-257.

16. Wheeler-Kingshott CA, Stroman PW, Schwab JM, Bacon M, Bosma R, Brooks J, Cadotte DW, Carlstedt T, Ciccarelli O, Cohen-Adad J, Curt A, Evangelou N, Fehlings MG, Filippi M, Kelley BJ, Kollias S, Mackay A, Porro CA, Smith S, Strittmatter SM, Summers P, Thompson AJ, Tracey I. The current state-of-the-art of spinal cord imaging. Applications, Neuroimage 2014; 84: 1082-1093.

17. Winklhofer S, Schoth F, Stolzmann P, Krings T, Mull M, Wiesmann M, Stracke CP. Spinal cord motion: influence of respiration and cardiac cycle fortschr röntgenstr 2014; 186(11): 1016-1021.

18. Zecca C, Cereda C, Wetzel S, Tschuor S, Staedler C, Santini F, Nadarajah N, Bassetti CL, Gobbi C. Diffusion-weighted imaging in acute demyelinating myelopathy. Neuroradiology 2012; 54: 573-578 